\title{
Marine Peptides as Potential Agents for the Management of Type 2 Diabetes Mellitus-A Prospect
}

\author{
En-Qin Xia, Shan-Shan Zhu, Min-Jing He, Fei Luo, Cheng-Zhan Fu and Tang-Bin Zou *
}

Dongguan Key Laboratory of Environmental Medicine, School of Public Health, Guangdong Medical University, Dongguan 523808, China; enqinxia@163.com (E.-Q.X.); zss90y@163.com (S.-S.Z.);

minjinghe0818@163.com (M.-J.H.); luofei_00@163.com (F.L.); fuchengzhan@126.com (C.-Z.F.)

* Correspondence: zoutb@163.com; Tel.: +86-769-2289-6572

Academic Editor: Se-Kwon Kim

Received: 30 January 2017; Accepted: 20 March 2017; Published: 23 March 2017

\begin{abstract}
An increasing prevalence of diabetes is known as a main risk for human health in the last future worldwide. There is limited evidence on the potential management of type 2 diabetes mellitus using bioactive peptides from marine organisms, besides from milk and beans. We summarized here recent advances in our understanding of the regulation of glucose metabolism using bioactive peptides from natural proteins, including regulation of insulin-regulated glucose metabolism, such as protection and reparation of pancreatic $\beta$-cells, enhancing glucose-stimulated insulin secretion and influencing the sensitivity of insulin and the signaling pathways, and inhibition of bioactive peptides to dipeptidyl peptidase IV, $\alpha$-amylase and $\alpha$-glucosidase activities. The present paper tried to understand the underlying mechanism involved and the structure characteristics of bioactive peptides responsible for its antidiabetic activities to prospect the utilization of rich marine organism proteins.
\end{abstract}

Keywords: marine protein; bioactive peptide; regulation; glucose metabolism; structure active relationship

\section{Introduction}

Diabetes mellitus is known as a seriously chronic metabolism disorder. According to the forecast, the prevalence of type 2 diabetes mellitus (T2DM) will increase from 350 million today to 592 million by 2035 [1]. The nutrient overload in prolonged periods was the key factor causing the bad situation due to impairing the pancreatic $\beta$ cell function. In sequence, insulin resistance, the impaired secretary insulin and glucose tolerance become true, and the following result is to develop T2DM [2-4]. Fortunately, recent studies of Zhu et al. suggest that peptides and protein hydrolysates from wild Chum Salmon (Oncorhynchus kern) skin markedly decreased the level of fasting glucose level and the pancreatic apoptosis of islet cells [5]. Pandey et al. reported that the bacteria associated with marine sponge, Aka coralliphaga, produce many glucosidase inhibitory peptides [6]. Among marine microalgae, Chlorella vulgaris (C. vulgaris) is regarded as a complementary medicine, due to its supplements, and exhibited benefits for some health disorders, such as dyslipidemia, hyperglycemia, and hypertension as well as weight loss in several studies [7,8]. These results indicated that the natural marine bioactive peptides can improve the deleterious process of T2DM. However, few reports involved antidiabetic activities of marine natural peptides can be found in literature in our knowledge. Therefore, the present review will summarize all evidence on antidiabetic activities of natural peptides from milk, bean and marine organisms. Its primary coverage involved the response of insulin-regulated glucose metabolism and dipeptidyl peptidase IV (DPP-IV), $\alpha$-amylase and $\alpha$-glucosidase activities on the bioactive peptides. The mechanism underlying each antidiabetic 
activity and the structure characteristics of bioactive peptides responsible for its antidiabetic activities were also carefully discussed for the future novel marine peptides investigation.

\section{Regulation of Bioactive Peptides on the Insulin-Regulated Glucose Metabolism}

\subsection{Protecting Pancreatic $\beta$-Cells of Bioactive Peptides}

Adequate insulin secretion is necessary to maintain blood glucose levels within a physiological range, and competent pancreatic $\beta$-cells are responsible for that task. However, it becomes insufficient for the T2DM individuals due to their pancreatic $\beta$-cell failure [9]. The major factor causing the adverse effect on pancreatic $\beta$ cells was reported as chronic nutrient overload, which causes a cell to increase its function and mass to match the increasing nutrient availability and insulin resistance [10]. As it can not adapt to maintaining glucose homeostasis at the high glucose challenges over prolonged periods [4], hyperglycemia was developed, which was verified to generate over-production of free radical species including reactive oxygen species (ROS) and nitric oxide (NO) radicals. These free radicals can cause defects in the mitochondrial respiratory chain by excessive requirements of oxidative enzymes activities (e.g., NOX), protein glycation and non-enzymatic oxidation and peroxidation of carbohydrates and lipids, and so on. Ultimately, increasing oxygen free radicals generate in various tissues including pancreas and kidneys [11-13]. Based on in vitro cell models and animal models of diabetes assays, researchers found that increased intracellular ROS production can significantly promote peripheral insulin resistance and induce endoplasmic reticulum (ER) stress, mitochondrial dysfunction, apoptosis and cell death. Subsequently, pancreatic $\beta$ cell mass become deficient and its secretory function was impaired [14-20]. Using Min6 cells and pancreatic islets, Mailloux and coworkers found that an increase in mitochondrial matrix ROS can reverse the glutathionylation of uncoupling protein-2, which subsequently impedes glucose-stimulated insulin secretion from $\beta$ cells [21]. In addition, it is reported that insulin-secreting $\beta$ cells of the pancreatic islets contain gene expression and activity of the $\mathrm{H}_{2} \mathrm{O}_{2}$-reducing enzymes catalase and glutathione peroxidase (GPx) in islets accounting for only $1 \%-5 \%$ of the values in liver, and levels of cytosolic and mitochondrial superoxide dismutases (SOD) in islets only around $30 \%$ of those in the liver [22,23]. Obviously, as induced by chronic hyperglycemia and exposure to proinflammatory cytokines, the poor antioxidant defense capability of pancreatic $\beta$ cells was sensitive towards oxidative stress [23-25]. Overexpression of these antioxidant enzymes has been observed to protect various $\beta$ cell lines against oxidative damage [26-28]. Reactive oxygen species sensitized by metallothionein and catalase in nonobese diabetic mice was predicted to protect the pancreatic $\beta$ cells from autoimmune destruction in male non-obese diabetic (NOD) [29]. Therefore, control of oxidative stress and inflammatory may be key approaches to reduce pancreatic $\beta$ cell damage and the development of T2DM [30].

Recently, researchers reported that natural nutrient metabolites can exert a significant role to preserve $\beta$ cell functions and mass, prolong the pre-diabetic phase and delay the progress to frank T2DM. For instance, consumption of dairy products was found linking with a decrease in the risk of type 2 diabetes [31,32]. Nasri et al. also reported that orally administered goby fish protein hydrolysates, not undigested goby fish protein, can significantly attenuate hyperglycemia and restored the antioxidant status under high-fat-high-fructose diet-induced oxidative stress in rats [33]. The same results reported that the effectiveness of the natural administration of fish protein hydrolysates, produced from Sardinella aurita and Salaria basilisca, in improving the oxidative status antioxidant for cholesterol-fed rats and alloxan-induced diabetic rats, respectively [34,35]. The results suggest that the presence of potent active peptides in fish protein hydrolysates was effective in enhancement of the antioxidant status.

Using in vitro assays, scavenging free radical capacity of bioactive peptides was observed by several researchers [14,36-38]. After being treated with pinto Durango bean (P. vulgaris L.) alcalase hydrolysates for $20 \mathrm{~h}$ at the concentration of $100 \mu \mathrm{g} / \mathrm{mL}$, ROS production due to tertbutyl hydroperoxide (t-BOOH) was almost eradicated in in vitro cell assay [36]. Fernández-Tomé [37] also found that lunasin, a soy peptide, exerted an effective scavenger as high as $190 \%$ of the intracellular 
ROS generation in HepG2 cells due to exposed to t-BOOH, compared to the control. In addition, the receptor in HepG2 cells for advanced glycation end products (RAGE) showed the lowest expression treated with the complete protein hydrolysates. While RAGE was found in pancreatic islets acting as an inducer of pancreatic $\beta$-cell apoptosis and developing of chronic diabetic complications via nicotinamide adenine dinucleotide phosphate oxidase mediated ROS generation in vitro assays [38]. Treatment with $\beta$-casomorphin-7, a milk-derived bioactive peptide, a considerable reduction in $\mathrm{H}_{2} \mathrm{O}_{2}$ content $(p<0.05)$ and a remarkable increase in the activity of GSH-peroxidase, SOD and catalase of the anti-oxidation system were observed. Simultaneously, the abatement of free-radical-mediated oxidative stress in blood and myocardium and cardiac indexes were also observed [39]. Protective effect of peptides on pancreatic $\beta$-cells against intracellular ROS due to a high glucose exposure has also been observed [14].

Natural peptides were also reported to efficiently ameliorate the diabetes symptoms. The levels of blood glucose of streptozotocin-induced diabetic rats markedly decreased after treatment with $\beta$-casomorphin-7, compared with model control group $(p<0.01)$ [39]. Bioactive peptides were observed to reduce the expression of cytokines such as interleukin- $1 \beta$ and tumor necrosis factor- $\alpha$ in pancreatic $\beta$-cells, which both generate as the cells were exposed to high glucose in vitro [40]. A Chlorella-11 peptide was also able to suppress lipopolysaccharide-induced nitric oxide (NO), serum TNF- $\alpha$ and inflammation [41]. In addition, it was reported that the common bean peptides can upregulated the expression of insulinlike growth factor 2 (IGF-II), a kind of adipokines in pancreatic $\beta$-cells now being believed to play a negative role in the development of obesity-associated insulin resistance and anti-inflammation [42].

\subsection{Enhancement of Glucose-Stimulated Insulin Secretion}

It has been revealed that T2DM develops when the insulin secretory capacity is unable to compensate for the increase of insulin resistance. The incretins, gut-derived hormones released from small intestine enteroendocrine cells (EECs), i.e., glucagonlike peptide 1 (GLP-1) and glucose dependent insulinotropic peptide (GIP), exert the significant role in regulation of food digestion by stimulation of glucose-dependent insulin secretion, as well food intake by promoting satiety to decrease appetite [43-45]. However, studies showed that circulating GLP-1 levels increase after meal intake but rapidly decrease $80 \%-90 \%$ due to cleaved by dipeptidyl peptidase IV (DDP-IV) [46]. Therefore, the DPP-IV inhibitors have indirect effects on islet function via contributing to insulin secretion and lowering blood glucose by increasing incretin action [47]. As early as 1988, Liddle et al. found that protein digestion can stimulate gut hormone secretion and expression in rats [48]. According to Caron et al., intestinal digestion derived from bovine haemoglobin exhibited significant efficiency on gut hormone release and DPP-IV activity inhibition, and those hormones' gene expression was also up-expressed [49]. The DPP-IV inhibition capacity of some diet origin peptides above $200 \mu \mathrm{M}$ of in literature is displayed in Table 1.

Table 1. The precursors, sequences, inhibition capacity (IC 50) of some natural origin peptides with dipeptidyl peptidase IV inhibitory activity in literature with IC $50<200 \mu \mathrm{M}$.

\begin{tabular}{|c|c|c|c|c|}
\hline Food & Precursor Protein & Peptide Sequence & IC $50(\mu \mathrm{M})$ & Reference \\
\hline Plant Protein & $\begin{array}{c}\text { Macroalga Palmaria } \\
\text { palmate protein }\end{array}$ & $\begin{array}{c}\text { ILAP } \\
\text { LLAP } \\
\text { MAGVDHI }\end{array}$ & $\begin{array}{c}43.40 \\
53.67 \\
159.37\end{array}$ & [50] \\
\hline \multirow{3}{*}{ Collagen } & $\begin{array}{l}\text { Halibut skin } \\
\text { gelatin }\end{array}$ & $\begin{array}{c}\text { SPGSSGPQGFTG } \\
\text { GPVGPAGNPGANGLN } \\
\text { PPGPTGPRGQPGNIGF }\end{array}$ & $\begin{array}{l}101.6 \\
81.3 \\
146.7\end{array}$ & \multirow{2}{*}{ [51] } \\
\hline & Tilapia skin gelatin & $\begin{array}{c}\text { IPGDPGPPGPPGP } \\
\text { LPGERGRPGAPGP } \\
\text { GPKGDRGLPGPPGRDG }\end{array}$ & $\begin{array}{l}65.4 \\
76.8 \\
89.6\end{array}$ & \\
\hline & $\begin{array}{l}\text { Tuna cooking juice } \\
\text { hydrolysates }\end{array}$ & $\begin{array}{c}\text { PACGGFWISGRPG } \\
\text { CAYQWQRPVDRIR } \\
\text { PGVGGPLGPIGPCYE }\end{array}$ & $\begin{array}{c}96.4 \\
78 \\
116.1\end{array}$ & [52] \\
\hline
\end{tabular}


Table 1. Cont.

\begin{tabular}{|c|c|c|c|c|}
\hline Food & Precursor Protein & Peptide Sequence & IC $50(\mu \mathrm{M})$ & Reference \\
\hline Collagen & Deer skin protein & $\begin{array}{l}\text { GPVGXAGPPGK } \\
\text { GPVGPSGPXGK }\end{array}$ & $\begin{array}{l}83.3 \\
93.7\end{array}$ & {$[53]$} \\
\hline \multirow{6}{*}{ Milk protein } & $\alpha$-Lactalbumin & $\begin{array}{c}\text { LKPTPEGDL } \\
\text { LAHKALCSEKL } \\
\text { LCSEKLDQ } \\
\text { TKCEVFRE }\end{array}$ & $\begin{array}{c}45 \\
165 \\
186 \\
166\end{array}$ & [54] \\
\hline & $\beta$-Lactalbumin & $\begin{array}{l}\text { VAGTWY } \\
\text { IPAVF }\end{array}$ & $\begin{array}{l}174 \\
44.7\end{array}$ & $\begin{array}{l}{[55]} \\
{[56]}\end{array}$ \\
\hline & $\begin{array}{l}\text { Atlantic salmon } \\
\text { collagen/gelatin }\end{array}$ & $\begin{array}{l}\text { GPAE } \\
\text { GPGA }\end{array}$ & $\begin{array}{l}49.6 \\
41.9\end{array}$ & [52] \\
\hline & Gouda-type cheese & $\begin{array}{l}\text { VPITPTL } \\
\text { VPITPT } \\
\text { LPQNIPPL } \\
\text { VAGTWY } \\
\text { LPQ }\end{array}$ & $\begin{array}{c}110 \\
130 \\
46 \\
174 \\
82\end{array}$ & [57] \\
\hline & Whey protein & $\begin{array}{c}\text { LAHKALCSEKL } \\
\text { WLAHKALCSEKLDQ } \\
\text { LKPTPEGDL } \\
\text { LKPTPEGDLEIL } \\
\text { WLAHKALCSEKLDQ } \\
\text { WR } \\
\text { IPIQY } \\
\text { WCKDDQNPHS } \\
\text { TKCEVFRE } \\
\text { IPA } \\
\text { VA3, VL, WL, WI } \\
\text { LKPTPEGDLE } \\
\text { LKALPMH }\end{array}$ & $\begin{array}{c}165 \\
141 \\
459 \\
57 \\
141 \\
31.4 \\
28.2 \\
75.0 \\
166 \\
49 \\
<170 \\
42 \\
193\end{array}$ & [58-63] \\
\hline & Milk protein & $\begin{array}{c}\text { WA } \\
\text { WR } \\
\text { WK } \\
\text { LPYPY } \\
\text { WQ } \\
\text { WI } \\
\text { WN } \\
\text { YPYY }\end{array}$ & $\begin{array}{c}92.6 \\
37.8 \\
40.6 \\
108.3 \\
120.3 \\
138.7 \\
148.5 \\
194.4\end{array}$ & {$[46,64-66]$} \\
\hline Milk protein & Milk protein & $\begin{array}{l}\text { WN } \\
\text { IP } \\
\text { IPI } \\
\text { IPIQY } \\
\text { FLQP } \\
\text { WV } \\
\text { LPVPQ } \\
\text { IPM } \\
\text { HL } \\
\text { VA } \\
\text { WL } \\
\text { WP }\end{array}$ & $\begin{array}{c}148.5 \\
149.6 \\
3.5 \\
35.2 \\
65.3 \\
65.7 \\
48.2 \\
73.9 \\
143.2 \\
168.2 \\
43.6 \\
44.5\end{array}$ & {$[46,64-66]$} \\
\hline
\end{tabular}

From Table 1, milk is the main source of peptides with efficient DPP-IV inhibitors in literature. Skin from halibut, tilapia and deer also showed significant DPP-IV inhibition capacity with IC 50 lower than $200 \mu \mathrm{M}$. Plant proteins digested in vitro or in vivo have been investigated the DPP-IV inhibitory peptides by some researchers, such as cowpea bean [67], Quinoa [68], rice bran [69], raw amaranth flour, soybean flour, and wheat flour [70]. However, except for Macroalga Palmaria palmate, DPP-IV inhibition capacity were exhibited with IC 50 far higher than $200 \mu \mathrm{M}$. The collected data showed that novel original peptides from natural proteins, especially from marine organisms, have been widely investigated for the management of T2DM.

\subsection{Regulation of Glucose Uptake and Lipid Accumulation}

Hyperglycemia has been identified as a key factor to induce to deficiency in insulin secretion and/or decreased reaction of the organs to insulin (World Health Organization, 1999). Besides diet and lifestyle modifications, control and prevention of hyperglycemia are primary approaches in the management of diabetes mellitus, which is involved in several physiological processes, such as 
increasing utilization of the glucose by the peripheral tissues and lowering hepatic glucose output and adipocyte fat-accumulation [71].

Some studies showed that natural peptides can correct high blood sugar, even without regulation of insulin secretion. For instance, the bean hydrolysates from pinto Durango had a dose-dependent insulin sensitizing effect $(p<0.05)$ comparing to the control. The most potent fraction was pinto Durango-alcalase $<1 \mathrm{kDa}$, which caused insulin resistant cells to increase $(67 \pm 3.2) \%$ of glucose uptake compared to the non-insulin resistant cells [37]. The plasma glucose was also significantly decreased $(25 \%-34 \%)$, after simultaneously intervening rats high-fat-high-fructose diet (HFFD) and goby fish protein hydrolysates, compared to the HFFD group [33]. $\beta$-casomorphin- 7 , a peptide from milk, was also found to restrain the elevation of blood glucose, and its effect is slightly inferior to insulin $(11.18 \pm 0.72$ to $14.92 \pm 0.66 \mathrm{mmol} / \mathrm{L})$ [39]. The same results were found that the hypoglycemic effect of protein hydrolysates from muscle fish Zebra blenny in alloxan-induced diabetic rats [35] and from the vegetable Momordica charantia L. in alloxan-induced diabetic mice [33]. Yuh et al. found significantly enhanced hypoglycemic effects of chlorella consumption on streptozocin (STZ) induced diabetic mice [72]. By the similar assays, Jeong et al. observed significant improvement of insulin sensitivity in type 2 diabetic and normal Wistar rats., but the glucose-stimulated insulin secretion had not been influenced by chlorella consumption [73] Aglycin, a peptide from soy, exhibited effectively in preventing hyperglycemia in a diabetic animal model with impaired glucose tolerance and insulin resistance, which were induced in BALB/c mice (i.e., the laboratory bred strain of albino mice specially used for the study of cancer, neurological diseases) with a high-fat diet and received a single intraperitoneal injection of STZ [74]. Aglycin reduced blood glucose levels by $45.0 \%$ after long-term treatment (aglycin vs. model day $217.3 \pm 0.5 \mathrm{vs.} 11.3 \pm 0.4 \mathrm{mmol} / \mathrm{L}$; day $287.1 \pm 0.2$ vs. $12.4 \pm 0.6 \mathrm{mmol} / \mathrm{L}, \mathrm{Pb} .01$, respectively) [74]. The notable efficiency has also been observed by Veloso et al. [75]. However, insulin secretion and body weight control in aglycin treated mice was not affected. Glucose levels were lowered after insulin loading in aglycin-treated mice in the insulin tolerance test. It indicated that glucose control induced by aglycin is largely mediated by enhancing glucose utilization and insulin sensitivity in peripheral insulin target sites [74]. Peptides from salmon hydrolysate, separated by electrodialysis with filtration membrane, also enhanced glucose uptake in L6 skeletal muscle cells by up to $40 \%$ without insulin increase [76].

Recently, researchers found that there was an inverse relationship between amount of secretory adiponectin, known as an insulin sensitizor, and the percentage of adipose tissue in the internal organs. It indicates that the decreased fat accumulation may improve glucose tolerance by the enhancement of insulin sensitivity [77]. According to results of Toledo et al., lipid accumulation was inhibited from 13\% to $28 \%$ when adipocytes were treated with the bean hydrolysates throughout the differentiation process, and their $<1 \mathrm{kDa}$ peptide fraction showed slightly higher than whole hydrolysates [36]. Similarly, Martinez-Villaluenga et al. showed an inhibition of lipid accumulation from 27\% to $46 \%$ in 3T3-L1 adipocytes when treated with alcalase soy hydrolysates at a concentration of $100 \mu \mathrm{M}(1000 \mu \mathrm{g} / \mathrm{mL})$ with an average of molecular mass of $10 \mathrm{kDa}$ [78]. This study showed that common bean hydrolysates have the inhibitory effect on lipid accumulation. Lipid accumulation in adipose tissue can be reduced by different mechanisms, e.g., reducing lipid uptake through suppressing lipoprotein lipase or reducing lipid synthesis through inhibiting fatty acid synthase (FAS) [79]. To investigate the effect of peptides from natural protein on liquid accumulation, human white pre-adipocytes (HWP) received intervention from 11 peptides from fish, seaweed, shellfish, in order to investigate proliferation, differentiation and maturation. The results showed that Ala-Pro, Val-Ala-Pro and Ala-Lys-Lys greatly affected viability of HWP during the proliferation period, while Lys-Trp and Val-Trp reduced the number of viable cells during the differentiation stage. The decrease of their final lipid content and of the mRNA level of adipocyte markers (aP2, GLUT4, LPL and AGT) was also involved. Kim et al. showed that the peptide GAGVGY also downregulates lipid accumulation modulating of gene expression such as sterol regulatory element-binding proteins-1c, Peroxisome proliferator-activated receptor gamma and fatty acid synthase [80], which exhibited a dual effect regulating glucose uptake and lipid accumulation in a 
similar way as the present results [81-83]. In literature, some peptides from goat and soybean have been reported to inhibit growth of preadipocytes, decrease the differentiation process and decrease the final lipid content in human white preadipocytes and lipid accumulation [79,81]. These results suggest that natural peptides may be a potential compound on regulation of T2DM via inhibitory lipid accumulation.

\subsection{Regulation of the Insulin-Signaling Pathways}

Correction insulin resistance is an important therapeutic strategy for T2DM. Insulin resistance is a physiological condition, in which cells fail to respond to the normal actions of the hormone insulin, and reduction or impairment of insulin-stimulated glucose uptake. Insulin receptor substrate-1/phosphoinositide-3-kinase/protein kinase B (IRS-1/PI3K/Akt) signaling pathways was found as a main target to correct insulin regulating glucose uptake [84]. A defect in protein kinase $\mathrm{B}$ (PKB or Akt) signaling that reduces the translocation of the glucose transporter protein GLUT4 to the cellular membrane may be a main impairment of insulin-stimulated glucose uptake under insulin resistance conditions [85]. The action mechanism of IRS-1/PI3K/Akt signaling pathways on regulation of blood sugar is illustrated in Figure 1. In vivo assays showed that under insulin resistance of diabetes, phosphorylation level of Akt Ser473 decreases, and insulin signal transduction also significantly abates due to a decrease in insulin receptor concentration and kinase activity $[86,87]$. Therefore, insulin receptor (IR), insulin receptor substrate-1/2 (IRS-1/2), PI3K and Akt all might be efficient targets to regulate downstream signaling cascade to lower blood sugar level.

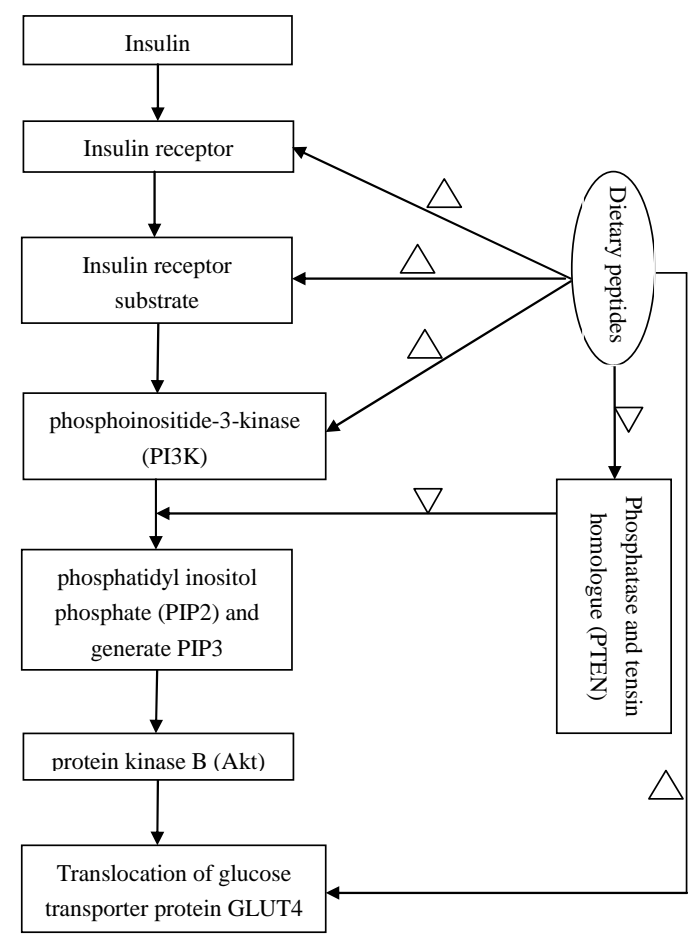

Figure 1. Some regulation evidence of natural peptides on the insulin-signaling pathways. Note: ' $\Delta$ ' and ' $\nabla$ ' mean the natural peptides display upregulation and downregulation on the corresponding bioprecessed, respectively.

Some evidence has reported on the upregulation of GLUT4 in T2DM individuals by natural peptides. The effect of aglycin, a peptide from soy, on insulin signaling in the mice skeletal muscle showed that a significant increase in the expression of IR and IRS1 genes, as well as total IR, IRS1, p-Akt protein and membrane GLUT4, was observed. An increase of $75 \%$ of basal glucose uptake was found in both normal and insulin-resistant $\mathrm{C} 2 \mathrm{C} 12$ cells [74]. B-casomorphin-7 and insulin 
increased $(p<0.05)$ 1.37-fold and 1.62-fold of the expression of GLUT-4 in myocardium, respectively. In contrast with the model group, soybean peptides also have been reported to improve insulin action via increasing the expressions of GLUT4 and insulin regulatory genes in diabetic animals [88,89]. The peptide GAGVGY, a fibroin derivative, increased both basal and insulin stimulated glucose uptake through enhancement of GLUT1 expression and PI3K-dependent GLUT4 translocation [80]. Tripeptides such as GEY and GYG, derived from the peptide E5K6 from silk, stimulated glucose uptake in 3T3-L1 adipocytes by inducing the expression of glucose transporters GLUT1 and GLUT4 [90].

In adipose tissue, insulin is also responsible for the enhanced uptake of glucose by GLUT4. When adipocytes show insulin resistance, GLUT4 does not translocate to cell membrane in response to insulin release by the pancreas, and this leads to reduced glucose uptake. Common bean peptides modulating glucose transporters in insulin resistant adipocyte 3T3-L1 were evaluated by confocal microscopy. Results showed that there was a dose-dependence between the upregulation expression of glucose transporters GLUT4 and fraction peptides with $<1 \mathrm{kDa}$ derived from alcalase and bromelain [36]. In addition, a fermented soybean extract significantly increased the expression of GLUT4 and glucose uptake in 3T3-L1 adipocytes [91].

In vivo assays showed that fat accumulation was strongly associated with the inhibition of the PI3k signaling pathway, which was involved in the inhibition of insulin signaling [92]. Recovery of the activity of PI3K/Akt could protect the liver from non-alcoholic fatty liver disease induced injury [93]. These results might explain the fact that long-term feeding of soy peptide induced weight loss in obese mice both in healthy and diabetic animal models [74,94].

In addition, Akt is one of the major downstream targets of PI3K and responsible for the physiological function of insulin in adipocytes [95]. Phosphatase and tensin homologue (PTEN) is a lipid phosphatase that downregulates the action of PI3K decreasing insulin signaling, playing a role in regulating glucose metabolism [96]. A reduction of PTEN was presented with pinto Durango-bromelain bean hydrolysate and its $<1 \mathrm{kDa}$ peptide fraction treatments [36].

\subsection{Clinical Trials}

In very rare clinical human studies on anti-diabetes peptides, the efficacy of Chlorella vulgaris (C. Vulgaris) in prevention and treatment of dyslipidemia, hyperglycemia, hypertension as well as weight loss was found in literature [97-99]. C. vulgaris, a single-celled marine green algae, has been regarded as a complementary medicine [100]. Studies showed consumption of chlorella tablets for 16 weeks led to ameliorate insulin signaling pathways and noticeable reduction in serum glucose concentrations [97]. Panahi et al. also reported that $C$. vulgaris supplementation results in a marked decrease in insulin resistance and fasting serum glucose level in non-alcoholic fatty liver disease (NAFLD) patients [98]. Recently, Ebrahimi-Mameghani et al. recruited 70 obese patients with NAFLD aged 20-50 years to interfere with $C$. vulgaris supplementation. The results showed that $1200 \mathrm{mg} \mathrm{C}$. vulgaris supplementation brought several potential beneficial effects, such as loss of weight, lowering serum glucose level, improvement of inflammatory biomarkers and liver function in NAFLD patients [99].

\section{Inhibition of Bioactive Peptides to $\alpha$-Amylase and $\alpha$-Glucosidase Activities}

Other approaches to decrease hyperglycemia are to control or delay glucose absorption by inhibition of $\alpha$-glucosidase or $\alpha$-amylase in the gastrointestinal tract. $\alpha$-amylase is an enzyme that hydrolyses $\alpha$-bonds polysaccharide such as glycogen and starch to oligosaccharides. $\alpha$-Glucosidase is present in the epithelial mucosa of the small intestine and cleaves glycosidic bonds in oligosaccharides, releasing monosaccharides into blood sugar [30,101]. Thus, inhibition of $\alpha$-amylase and $\alpha$-glucosidase is an alternative pathway to management of the blood glucose levels and T2DM [102].

A significant increase in the serum $\alpha$-amylase activity (by $86.08 \%$ ) was found in HFFD-fed rats compared to control rats $(p<0.05)$. As oral administration of goby fish protein hydrolysates, the $\alpha$-amylase activity in that of high-fat-high-fructose feed rats decreased by about $62 \%$ compared to 
the HFFD group [35]. Pinto bean peptides ( $<3 \mathrm{kDa}$ fraction) and cumin seed-derived peptides also showed $\alpha$-amylase inhibitory capacity at $62.1 \%$ and $24.54 \%$, respectively $[103,104]$. Some inhibitory peptides and its IC50 and sequences has been detected or identified in literature and are illustrated in Table 2. To our knowledge, reports about inhibitory $\alpha$-amylase peptides were limited, and less references could be obtained on the $\alpha$-glucosidase inhibitory peptides in literature.

Table 2. The sequences, inhibition capacity (IC 50) and precursors of natural peptides with $\alpha$-amylase and $\alpha$-glucosidase inhibitory activity in literature.

\begin{tabular}{|c|c|c|c|c|}
\hline Ingredient & Peptides Sequence & IC 50 & Precursors & Reference \\
\hline \multirow{6}{*}{$\alpha$-amylase } & $\begin{array}{c}\text { PPHMLP } \\
\text { PLPWGAGF } \\
\text { PPHMGGP } \\
\text { PLPLHMLP } \\
\text { LSSLEMGSLGALFVCM }\end{array}$ & $\begin{array}{c}1.97\left(\mathrm{mg} \mathrm{mL}^{-1}\right) \\
8.96\left(\mathrm{mg} \mathrm{mL}^{-1}\right) \\
14.63\left(\mathrm{mg} \mathrm{mL}^{-1}\right) \\
18.45\left(\mathrm{mg} \mathrm{mL}^{-1}\right) \\
20.56\left(\mathrm{mg} \mathrm{mL}^{-1}\right)\end{array}$ & Pinto bean & [103] \\
\hline & $\begin{array}{c}\text { FFRSKLLSDGAAAAKGALLPQYW } \\
\text { RCMAFLLSDGAAAAQQLLPQYW } \\
\text { DPAQPNYPWTAVLVFRH }\end{array}$ & $\begin{array}{l}0.02(\mu \mathrm{M}) \\
0.04(\mu \mathrm{M}) \\
0.03(\mu \mathrm{M})\end{array}$ & $\begin{array}{l}\text { Cumin seed } \\
\text { protein }\end{array}$ & [104] \\
\hline & $\begin{array}{l}\text { RCMAFLLSDGAAAAQQLLPQYW } \\
\text { DPAQPNYPW TAVLVFRH }\end{array}$ & $\begin{array}{l}0.04(\mu \mathrm{M}) \\
0.15(\mu \mathrm{M})\end{array}$ & $\begin{array}{l}\text { Cumin seed } \\
\text { protein }\end{array}$ & [105] \\
\hline & $\begin{array}{l}\text { WEVM } \\
\text { AKSPLF }\end{array}$ & - & Black bean protein & [106] \\
\hline & $<3 \mathrm{kDa}$ fraction & - & Rice bran protein & [107] \\
\hline & $\begin{array}{c}\text { KLPGF } \\
\text { NVLQPS }\end{array}$ & $\begin{array}{l}120.0 \pm 4.0(\mu \mathrm{M}) \\
110.0 \pm 6.2(\mu \mathrm{M})\end{array}$ & Albumin & [108] \\
\hline \multirow{3}{*}{$\alpha$-glucosidase } & - & $\begin{array}{c}36.3 \%-50.1 \% \mathrm{mg}^{-1} \\
\text { DW }\end{array}$ & Bean protein & [109] \\
\hline & TTGGKGGK & - & Black bean protein & [107] \\
\hline & $\begin{array}{c}\text { KLPGF } \\
\text { NVLQPS }\end{array}$ & $\begin{array}{c}59.5 \pm 5.7(\mu \mathrm{M}) \\
100.0 \pm 5.7(\mu \mathrm{M})\end{array}$ & Albumin & [108] \\
\hline
\end{tabular}

\section{The Structure Characteristics of Antidiabetes Peptides}

Different approaches have been suggested potential for the treatment and management of Type 2 diabetes by natural peptides. A limited number of studies focus on the structural features that govern the properties of peptides in literature, including the structure of DPP-IV inhibitory, insulinotropic and $\alpha$-amylase peptides.

For DPP-IV inhibitory peptides, they exert their effect by binding either at the active site and/or outside the catalytic center of the enzyme. In silico studies predicted that the active site of DPP-IV comprises a hydrophobic S1 (Tyr662 and Tyr666) pocket and a charged S2 (Phe357 and Arg125) pocket with an overall negative charge $[110,111]$. Hydrogen bonds and hydrophobic interactions were involved between N-terminal amino acids of DPP-IV inhibitory peptides and the catalytic active site of DPPIV. Thus, the structural features of DPP-IV inhibitors generally were inferred as a hydrophobic or aromatic amino acid at the N-terminus, such as Ile, Leu, Val, Phe, Trp or Tyr [52]. However, several non-inhibitory peptides possessing hydrophobic or aromatic amino acids at their N-terminus were also found (Table 1). Statistically, 77\% of all hydrophobic peptides (with an hydrophobicity index $>0$ ) and 53\% of the hydrophilic peptides were detected with DPP-IV inhibition [46]. It indicates that N-terminal hydrophobicity or aromaticity is a desirable characteristic, but not sufficient for inhibition.

To investigate the preferential amino acids involving in DPP-IV inhibition, the amount of each amino acid occurring in the DPP-IV inhibitory peptides was calculated based on Table 1. The preferential amino acids were also found as Pro, Leu, Gly, Ala, Trp in decreasing order, and Pro occurred most frequently in DDP-IV inhibitory peptides. Studies also showed that collagen from fish 
and mammals has also attracted notable attention as a potential source of DPP-IV inhibitory peptides partly due to its high content in Pro residue [51,52]. In addition, peptides with the presence of a Trp at the N-terminus was found as more potent DPP-IV inhibitors with an IC 50 value $<200 \mathrm{mM}$ [65]. A positive correlation between the presence of Trp-containing peptides within plant (hemp, pea, rice and soy) protein hydrolysates and their DPP-IV inhibitory properties have been observed [68].

However, containing the most preferring amino acid, i.e., Pro, Ile-Pro and Pro-Tyr were shown to be a DPP-IV inhibitor while Pro-Ile and Tyr-Pro were not $[69,112]$. The results indicated that the different stereochemistry between them may exert a role in the biological activity of the peptide. Indeed, the existence of exclusion volumes in the S1 pocket of DPP-IV might explain the results, which may restrict the access of bulky amino acids and allow access to smaller residues such as Pro, Ala and Gly [113].

In literature, hydrolysis fractions $(<1 \mathrm{kDa})$ of hard-to-cook bean proteins and whey proteins hydrolysis both showed insulin secretagogue action and improved insulin signaling in adipocytes $[36,114]$. In vitro studies using pancreatic $\beta$-cell lines or primary islet cells displayed significant insulinotropic effects of different amino acid residues, including Ala, Leu, Arg and Gln [115,116]. Without carbohydrates, only ingestion of amino acids (Leu, Arg, Ile, Phe and Ala) or milk-derived peptides also exhibited an increase of insulin secretion [117,118]. Furthermore, studies verified that branched chain amino acids were closely associated with insulinotropic effects $[115,116,119,120]$.

Investigation of whey protein hydrolysis showed that the most potent insulinotropic fractions obtained were hydrophilic, which might be responsible for the activity observed [114]. However, other peptides with hydrophobic characteristics may also contribute to the insulinotropic properties of the whey protein hydrolysate [63]. In addition, the levels of Arg and Phe were found to be associated with an insulinotropic activity [116]. According to the results above, it was inferred that free amino acids and dipeptides would be bioavailable and therefore may reach pancreatic $\beta$ cells in vivo.

The complex mechanisms of these amino acids exerting their action involve mitochondrial metabolism. During fasting periods, glutamine and alanine are important factors to modulate glucagon release from pancreatic $\alpha$-cells and subsequently influence insulin secretion from $\beta$-cells. On the other hand, high glucose levels raise ATP / ADP ratio in $\beta$-cells, and inhibit glutamate oxidation to amplify insulin signals [36].

The structural features of $\alpha$-amylase peptide inhibitor were investigated by Yu et al. [108]. The amino acids, such as Leu, Pro, Gly and Phe, are frequently found in $\alpha$-amylase inhibitory activity. Peptides with Pro at the N-terminal of Gly or Phe and C-terminal of Phe or Leu were found owning $\alpha$-amylase inhibitory activity. The positioning of these amino acids at the $\mathrm{N}$ - or $\mathrm{C}$-terminal were believed to be the contributors to $\alpha$-amylase inhibitory activity of peptides extracted from Pinto bean [121]. Some reports showed that the high molecular weights of amino acids with aromatic ring, such as Arg, Phe, Trp, and Tyr, were crucial for interacting with the active site of human pancreatic $\alpha$-amylases [104,122]. However, the results on the structural active relationship of $\alpha$-amylase inhibitor peptides are still limited and not many studies have been conducted. Evenly, the data on the structure features for peptides such as potential $\alpha$-glucosidase inhibitors have not been found in literature [108].

\section{Conclusions}

Nowadays, the discovery of novel ocean bioactive peptides is one of the most exciting new directions of pharmaceutical science due to their nutritional attributes, large output and uniqueness in terms of diversity, and structural and functional features with respect to peptides isolated from terrestrial plants. The diverse nature of T2DM means that food ingredients, such as natural peptides, will be more suitable for combating it and its associated complications than the synthetic and other drugs with significant side effects in the long term. This review concluded that natural origin peptides derived from several kinds of marine organisms, for instance, macro- and micro-algae, marine sponge, fish skin gelatin, and even tuna cooking juice hydrolysates, besides from milk and beans, showed great 
potential to regulate glucose metabolism for insulin resistance individuals. Chlorella vulgaris, one type of marine microalgae with large biomass and high quality protein accounting for over $60 \%(\mathrm{Wt})$, has been reported with significant antidiabetic activities in rare clinical trials. This evidence suggested that valuable antidiabetic activities associated with marine bioactive peptides, especially derived from marine microorganisms and their metabolites might be used in future potentialities in nutraceutical and pharmaceutical industries. Investigation of the structural features of peptides linked with anti-diabetic activity, using bioinformatics combined with molecular biological technology, will be a powerful tool to exploit new peptides from abundant marine proteins. In addition, the performances of research studies using human models or clinical trials are necessary in the future for their further application.

Acknowledgments: This work was supported by grants from the National Natural Science Foundation of China (81302416), the Guangdong Science and Technology Planning Project (2014A020212297), the Guangdong Training Plan for Outstanding Young Teachers (YQ201405), the Dongguan Science and Technology Planning Project (2014108101053), and a grant from the Dongguan Key Laboratory of Environmental Medicine.

Author Contributions: Tang-Bin Zou designed the review; En-Qin Xia and Shan-Shan Zhu analyzed and wrote drafts of the manuscript; Min-Jing He, Fei Luo and Cheng-Zhan Fu helped rewrite the revised manuscript; Tang-Bin Zou and En-Qin Xia revised the manuscript and approved it in its final form. All authors read and approved the final manuscript.

Conflicts of Interest: The author declares no conflict of interest.

\section{References}

1. Lee, J.E.; Min, S.H.; Lee, D.H.; Oh, T.J.; Kim, K.M.; Moon, J.H.; Choi, S.H.; Park, K.S.; Jang, H.C.; Lim, S. Comprehensive assessment of lipoprotein subfraction profiles according to glucose metabolism status, and association with insulin resistance in subjects with early-stage impaired glucose metabolism. Int. J. Cardiol. 2016, 225, 327-331. [CrossRef] [PubMed]

2. Leavens, K.F.; Birnbaum, M.J. Insulin signaling to hepatic lipid metabolism in health and disease. Crit. Rev. Biochem. Mol. Biol. 2011, 46, 200-215. [CrossRef] [PubMed]

3. So, W.Y.; Leung, P.S. Irisin ameliorates hepatic glucose/lipid metabolism and enhances cell survival in insulin-resistant human HepG2 cells through adenosine monophosphate-activated protein kinase signaling. Int. J. Biochem. Cell Biol. 2016, 78, 237-247. [PubMed]

4. Maulucci, G.; Daniel, B.; Cohen, O.; Avrahami, Y.; Sasson, S. Hormetic and regulatory effects of lipid peroxidation mediators in pancreatic $\beta$ cells. Mol. Aspects Med. 2016, 49, 49-77. [CrossRef] [PubMed]

5. Zhu, C.F.; Peng, H.B.; Liu, G.Q.; Zhang, F.; Li, Y. Beneficial effects of oligopeptides from marine salmon skin in a rat model of type 2 diabetes. Nutrition 2010, 26, 1014-1020. [CrossRef] [PubMed]

6. Pandey, S.; Sree, A.; Dash, S.S.; Sethi, D.P.; Chowdhury, L. Diversity of marine bacteria producing $\beta$-glucosidase inhibitors. Microb. Cell Fact. 2013, 12, 35. [CrossRef] [PubMed]

7. Shibata, S.; Hayakawa, K.; Egashira, Y.; Sanada, H. Hypocholesterolemic mechanism of Chlorella: Chlorella and its indigestible fraction enhance hepatic cholesterol catabolism through upregulation of cholesterol $7 \alpha$-hydroxylase in rats. Biosci. Biotechnol. Biochem. 2007, 71, 916-925. [CrossRef] [PubMed]

8. Mello-Sampayo, C.; Luisa-Corvo, M.; Mendes, R.; Duarte, D.; Lucas, J.; Pinto, R. Insights on the safety of carotenogenic Chlorella vulgaris in rodents. Algal Res. 2013, 2, 409-915.

9. Belgardt, B.F.; Ahmed, K.; Spranger, M.; Latreille, M.; Denzler, R.; Kondratiuk, N.; von, Meyenn, F.; Villena, F.N.; Herrmanns, K.; Bosco, D.; et al. The microRNA-200 family regulates pancreatic $\beta$ cell survival in type 2 diabetes. Nat. Med. 2015, 21, 619-627. [CrossRef] [PubMed]

10. Kaiser, N.; Leibowitz, G. Failure of $\beta$-cell adaptation in type 2 diabetes Lessons from animal models. Front. Biosci. (Landmark Ed). 2009, 14, 1099-1115. [CrossRef] [PubMed]

11. Houstis, N.; Rosen, E.D.; Lander, E.S. Reactive oxygen species have a causal role in multiple forms of insulin resistance. Nature 2006, 440, 944-948. [CrossRef] [PubMed]

12. Khan, S.R. Is oxidative stress; a link between nephrolithiasis and obesity; hypertension; diabetes; chronic kidney disease; metabolic syndrome? Urol. Res. 2012, 40, 95-112. [CrossRef] [PubMed]

13. Roberts, C.K.; Sindhu, K.K. Oxidative stress and metabolic syndrome. Life Sci. 2009, 84, 705-712. [PubMed] 
14. Fernandez-Millan, E.; Cordero-Herrera, I.; Ramos, S.; Escriva, F.; Alvarez, C.; Goya, L.; Martin, M.A. Cocoa-rich diet attenuates $\beta$ cell mass loss and function in young Zucker diabetic fatty rats by preventing oxidative stress and $\beta$ cell apoptosis. Mol. Nutr. Food Res. 2015, 59, 820-824. [CrossRef] [PubMed]

15. Bayod, S.; Del, Valle, J.; Lalanza, J.F.; Sanchez-Roige, S.; de Luxan-Delgado, B.; Coto-Montes, A.; Canudas, A.M.; Camins, A.; Escorihuela, R.M.; Pallas, M. Long-term physical exercise induces changes in sirtuin 1 pathway and oxidative parameters in adult rat tissues. Exp. Gerontol. 2012, 47, 925-935. [CrossRef] [PubMed]

16. Carnagarin, R.; Dharmarajan, A.M.; Dass, C.R. PEDF-induced alteration of metabolism leading to insulin resistance. Mol. Cell Endocrinol. 2015, 40, 98-104.

17. Cnop, M.; Igoillo-Esteve, M.; Cunha, D.A.; Ladriere, L.; Eizirik, D.L. An update on lipotoxic endoplasmic reticulum stress in pancreatic $\beta$-cells. Biochem. Soc. Trans. 2008, 36, 909-915.

18. Lenzen, S. Oxidative stress the vulnerable $\beta$-cell. Biochem. Soc. Trans. 2008, 36, 343-347. [CrossRef] [PubMed]

19. Newsholme, P.; Haber, E.P.; Hirabara, S.M.; Rebelato, E.L.; Procopio, J.; Morgan, D.; Oliveira-Emilio, H.C.; Carpinelli, A.R.; Curi, R. Diabetes associated cell stress and dysfunction: Role of mitochondrial and non-mitochondrial ROS production and activity. J. Physiol. 2007, 583, 9-24. [CrossRef] [PubMed]

20. Poitout, V.; Amyot, J.; Semache, M.; Zarrouki, B.; Hagman, D.; Fontes, G. Glucolipotoxicity of the pancreatic $\beta$ cell. Biochim. Biophys. Acta 2010, 1801, 289-298. [CrossRef]

21. Mailloux, R.J.; Fu, A.; Robson-Doucette, C.; Allister, E.M.; Wheeler, M.B.; Screaton, R.; Harper, M.E. Glutathionylation state of uncoupling protein-2 and the control of glucose-stimulated insulin secretion. J. Biol. Chem. 2012, 287, 39673-39685. [PubMed]

22. Lenzen, S.; Drinkgern, J.; Tiedge, M. Low antioxidant enzyme gene expression in pancreatic islets compared with various other mouse tissues. Free Radic. Biol. Med. 1996, 20, 463-466. [PubMed]

23. Tiedge, M.; Lortz, S.; Drinkgern, J.; Lenzen, S. Relation between antioxidant enzyme gene expression and antioxidative defense status of insulin-producing cells. Diabetes 1997, 46, 1733-1742. [PubMed]

24. Corbett, J.A.; Wang, J.L.; Hughes, J.H.; Wolf, B.A.; Sweetland, M.A.; Lancaster, J.R.; McDaniel, M.L. Nitric oxide and cyclic GMP formation induced by interleukin $1 \beta$ in islets of Langerhans. Evidence for an effector role of nitric oxide in islet dysfunction. Biochem. J. 1992, 287, 229-235. [PubMed]

25. Morgan, D.; Oliveira-Emilio, H.R.; Keane, D.; Hirata, A.E.; Santos, da, Rocha, M.; Bordin, S.; Curi, R.; Newsholme, P.; Carpinelli, A.R. Glucose, palmitate and pro-inflammatory cytokines modulate production and activity of a phagocyte-like NADPH oxidase in rat pancreatic islets and a clonal $\beta$ cell line. Diabetologia 2007, 50, 359-369. [PubMed]

26. Lei, X.G.; Vatamaniuk, M.Z. Two tales of antioxidant enzymes on $\beta$ cells and diabetes. Antioxid. Redox Signal. 2011, 14, 489-503. [PubMed]

27. Tiedge, M.; Lortz, S.; Munday, R.; Lenzen, S. Protection against the co-operative toxicity of nitric oxide and oxygen free radicals by overexpression of antioxidant enzymes in bioengineered insulin-producing RINm5F cells. Diabetologia 1999, 42, 849-855.

28. Wolf, G.; Aumann, N.; Michalska, M.; Bast, A.; Sonnemann, J.; Beck, J.F.; Lendeckel, U.; Newsholme, P.; Walther, R. Peroxiredoxin III protects pancreatic ss cells from apoptosis. J. Endocrinol. 2010, 207, 163-175. [PubMed]

29. Li, X.; Chen, H.; Epstein, P.N. Metallothionein and catalase sensitize to diabetes in nonobese diabetic mice reactive oxygen species may have a protective role in pancreatic $\beta$-cells. Diabetes 2006, 55, 1592-1604. [PubMed]

30. Ibrahim, M.A.; Koorbanally, N.A.; Islam, M.S. Antioxidative activity and inhibition of key enzymes linked to type-2 diabetes ( $\alpha$-glucosidase and $\alpha$-amylase) by Khaya senegalensis. Acta Pharm. 2014, 64, 311-324. [CrossRef]

31. Choi, H.K.; Willett, W.C.; Stampfer, M.J.; Rimm, E.; Hu, F.B. Dairy consumption and risk of type 2 diabetes mellitus in men a prospective study. Arch. Intern. Med. 2005, 165, 997-1003. [PubMed]

32. Tremblay, A.; Gilbert, J.A. Milk products; insulin resistance syndrome and type 2 diabetes. J. Am. Coll. Nutr. 2009, 28 (Suppl. S1), 91S-102S. [PubMed]

33. Nasri, R.; Abdelhedi, O.; Jemil, I.; Daoued, I.; Hamden, K.; Kallel, C.; Elfeki, A.; Lamri-Senhadji, M.; Boualga, A.; Nasri, M.; et al. Ameliorating effects of goby fish protein hydrolysates on high-fat-high-fructose diet-induced hyperglycemia; oxidative stress and deterioration of kidney function in rats. Chem-Biol. Interact. 2015, 24, 271-280. 
34. Ben, Khaled, H.; Ghlissi, Z.; Chtourou, Y.; Hakim, A.; Ktari, N.; Fatma, M.A.; Barkia, A.; Sahnoun, Z.; Nasri, M. Effect of protein hydrolysates from sardinelle (Sardinella. aurita) on the oxidative status and blood lipid profile of cholesterol-fed rats. Food Res. Int. 2012, 45, 60-68.

35. Ktari, N.; Nasri, R.; Mnafgui, K.; Hamden, K.; Belguith, O.; Boudaouara, T.; El, Feki, A.; Nasri, M. Antioxidative and ACE inhibitory activities of protein hydrolysates from zebra blenny (Salaria. basilisca) in alloxan-induced diabetic rats. Process Biochem. 2014, 49, 890-897.

36. Oseguera, Toledo, M.E.; Gonzalez de Mejia, E.; Sivaguru, M.; Amaya-Llano, S.L. Common bean (Phaseolus. vulgaris L.) protein-derived peptides increased insulin secretion; inhibited lipid accumulation; increased glucose uptake and reduced the phosphatase and tensin homologue activation in vitro. J. Func. Foods 2016, 27, 160-177.

37. Fernández-Tomé, S.; Ramos, S.; Cordero-Herrera, I.; Recio, I.; Goya, L.; Hernández-Ledesma, B. In vitro chemo-protective effect of bioactive peptide lunasin against oxidative stress in human HepG2 cells. Food Res. Int. 2014, 62, 793-800.

38. Lee, K.W.; Kim, S.J. Uptake of modified LDLs in HepG2 cells and cholesterol accumulation by modified LDLs in THP-1 macrophages. Toxicol. Lett. 2010, 196, s243. [CrossRef]

39. Han, D.N.; Zhang, D.H.; Wang, L.P.; Zhang, Y.S. Protective effect of $\beta$-casomorphin-7 on cardiomyopathy of streptozotocin-induced diabetic rats via inhibition of hyperglycemia and oxidative stress. Peptides 2013, 44, 120-126. [CrossRef]

40. Donath, M.Y.; Storling, J.; Maedler, K.; Mandrup-Poulsen, T. Inflammatory mediators and islet $\beta$-cell failure a link between type 1 and type 2 diabetes. J. Mol. Med. (Berl.). 2003, 81, 455-470. [CrossRef]

41. Cherng, J.Y.; Liu, C.C.; Shen, C.R.; Lin, H.H.; Shih, M.F. Beneficial effects of Chlorella-11 peptide on blocking LPS-induced macrophage activation and alleviating thermal injury-induced inflammation in rats. Int. J. Immuno. Pathol. Pharmacol. 2010, 23, 811-820. [CrossRef] [PubMed]

42. Polyzos, S.A.; Kountouras, J.; Mantzoros, C.S. Adipokines in nonalcoholic fatty liver disease. Metabolism 2016, 65, 1062-1079. [PubMed]

43. Moran, T.H.; Dailey, M.J. Minireview Gut peptides targets for antiobesity drug development? Endocrinology 2009, 150, 2526-2530. [PubMed]

44. Perry, B.; Wang, Y. Appetite regulation and weight control the role of gut hormones. Nutr. Diabetes 2012, 2, e26. [CrossRef] [PubMed]

45. Troke, R.C.; Tan, T.M.; Bloom, S.R. The future role of gut hormones in the treatment of obesity. Ther. Adv. Chronic Dis. 2014, 5, 4-14.

46. Nongonierma, A.B.; FitzGerald, R.J. Inhibition of dipeptidyl peptidase IV (DPP-IV) by proline containing casein-derived peptides. J. Funct. Foods 2013, 5, 1909-1917.

47. Omar, B.; Ahlkvist, L.; Yamada, Y.; Seino, Y.; Ahren, B. Incretin hormone receptors are required for normal $\beta$ cell development and function in female mice. Peptides 2016, 79, 58-65. [CrossRef] [PubMed]

48. Liddle, R.A.; Carter, J.D.; McDonald, A.R. Natural regulation of rat intestinal cholecystokinin gene expression. J. Clin. Invest. 1988, 81, 2015-2019.

49. Caron, J.; Domenger, D.; Belguesmia, Y.; Kouach, M.; Lesage, J.; Goossens, J.F.; Dhulster, P.; Ravallec, R.; Cudennec, B. Protein digestion and energy homeostasis How generated peptides may impact intestinal hormones? Food Res. Int. 2016, 88, 310-318.

50. Harnedy, P.A.; O'Keeffe, M.B.; FitzGerald, R.J. Purification and identification of dipeptidyl peptidase (DPP) IV inhibitory peptides from the macroalga Palmaria. palmata. Food Chem. 2015, 172, 400-406. [PubMed]

51. Wang, T.Y.; Hsieh, C.H.; Hung, C.C.; Jao, C.L.; Chen, M.C.; Hsu, K.C. Fish skin gelatin hydrolysates as dipeptidyl peptidase IV inhibitors and glucagon-like peptide-1 stimulators improve glycaemic control in diabetic rats: A comparison between warm- and cold-water fish. J. Func. Foods 2015, 18, 330-340.

52. Huang, S.L.; Jao, C.L.; Ho, K.P.; Hsu, K.C. Dipeptidyl-peptidase IV inhibitory activity of peptides derived from tuna cooking juice hydrolysates. Peptides 2012, 35, 114-121. [CrossRef] [PubMed]

53. Jin, Y.; Yan, J.; Yu, Y.; Qi, Y. Screening and identification of DPP-IV inhibitory peptides from deer skin hydrolysates by an integrated approach of LC-MS/MS and in silico analysis. J. Funct. Foods 2015, 18, 344-357. [CrossRef]

54. Lacroix, I.M.; Li-Chan, E.C. Overview of food products and natural constituents with antidiabetic properties and their putative mechanisms of action a natural approach to complement pharmacotherapy in the management of diabetes. Mol. Nutr. Food Res. 2014, 58, 61-78. [CrossRef] [PubMed] 
55. Uchida, M.; Ohshiba, Y.; Mogami, O. Novel dipeptidyl peptidase-4-inhibiting peptide derived from $\beta$-lactoglobulin. J. Pharmacol. Sci. 2011, 117, 63-66. [CrossRef] [PubMed]

56. Silveira, S.T.; Martinez-Maqueda, D.; Recio, I.; Hernandez-Ledesma, B. Dipeptidyl peptidase-IV inhibitory peptides generated by tryptic hydrolysis of a whey protein concentrate rich in $\beta$-lactoglobulin. Food Chem. 2013, 141, 1072-1077. [PubMed]

57. Uenishi, K. Diabetes mellitus and osteoporosis. Natural therapy of diabetes related osteoporosis. Clin. Calcium. 2012, 22, 1398-1402. [PubMed]

58. Lacroix, I.M.; Li-Chan, E.C. Inhibition of dipeptidyl peptidase (DPP)-IV and $\alpha$-glucosidase activities by pepsin-treated whey proteins. J. Agric. Food Chem. 2013, 61, 7500-7506. [CrossRef]

59. Lacroix, I.M.; Li-Chan, E.C. Isolation and characterization of peptides with dipeptidyl peptidase-IV inhibitory activity from pepsin-treated bovine whey proteins. Peptides 2014, 54, 39-48. [CrossRef] [PubMed]

60. Lacroix, I.M.; Li-Chan, E.C. Comparison of the susceptibility of porcine and human dipeptidyl-peptidase IV to inhibition by protein-derived peptides. Peptides 2015, 69, 19-25. [PubMed]

61. Lacroix, I.M.E.; Meng, G.; Cheung, I.W.Y.; Li-Chan, E.C.Y. Do whey protein-derived peptides have dual dipeptidyl-peptidase IV and angiotensin I-converting enzyme inhibitory activities? J. Funct. Foods 2016, 21, 87-96. [CrossRef]

62. Tulipano, G.; Sibilia, V.; Caroli, A.M.; Cocchi, D. Whey proteins as source of dipeptidyl dipeptidase IV (dipeptidyl peptidase-4) inhibitors. Peptides 2011, 32, 835-838. [CrossRef] [PubMed]

63. Le Maux, S.; Nongonierma, A.B.; FitzGerald, R.J. Improved short peptide identification using HILIC-MS/MS retention time prediction model based on the impact of amino acid position in the peptide sequence. Food Chem. 2015, 17, 3847-3854. [CrossRef]

64. Nongonierma, A.B.; FitzGerald, R.J. Dipeptidyl peptidase IV inhibitory and antioxidative properties of milk protein-derived dipeptides and hydrolysates. Peptides 2013, 39, 157-163. [CrossRef] [PubMed]

65. Nongonierma, A.B.; Mooney, C.; Shields, D.C.; FitzGerald, R.J. In silico approaches to predict the potential of milk protein-derived peptides as dipeptidyl peptidase IV (DPP-IV) inhibitors. Peptides 2014, 57, 43-51. [CrossRef] [PubMed]

66. Nongonierma, A.B.; FitzGerald, R.J. Strategies for the discovery; identification and validation of milk protein-derived bioactive peptides. Trends. Food Sci. Tec. 2016, 50, 26-43.

67. De Souza Rocha, T.; Hernandez, L.M.R.; Chang, Y.K.; de Mejía, E.G. Impact of germination and enzymatic hydrolysis of cowpea bean (Vigna. unguiculata) on the generation of peptides capable of inhibiting dipeptidyl peptidase IV. Food Res. Int. 2014, 64, 799-809.

68. Nongonierma, A.B.; Le, Maux, S.; Dubrulle, C.; Barre, C.; FitzGerald, R.J. Quinoa (Chenopodium. quinoa Willd.) protein hydrolysates with In Vitro dipeptidyl peptidase IV (DPP-IV) inhibitory and antioxidant properties. J. Cereal Sci. 2015, 65, 112-118.

69. Hatanaka, T.; Inoue, Y.; Arima, J.; Kumagai, Y.; Usuki, H.; Kawakami, K.; Kimura, M.; Mukaihara, T. Production of dipeptidyl peptidase IV inhibitory peptides from defatted rice bran. Food Chem. 2012, 134, 797-802. [PubMed]

70. Velarde-Salcedo, A.J.; Barrera-Pacheco, A.; Lara-Gonzalez, S.; Montero-Morán, G.M.; Díaz-Gois, A.; de Mejia, E.G.; Barba, de la Rosa, A.P. In Vitro inhibition of dipeptidyl peptidase IV by peptides derived from the hydrolysis of amaranth (Amaranthus hypochondriacus L.) proteins. Food Chem. 2013, 136, 758-764. [CrossRef] [PubMed]

71. Zeng, Z.; Shuai, T.; Yi, L.J.; Wang, Y.; Song, G.M. Effect of case management on patients with type 2 diabetes mellitus: A meta-analysis. Chinese Nursing Research 2016, 3, 71-76.

72. Jong-Yuh, C.; Mei-Fen, S. Potential hypoglycemic effects of Chlorella in streptozotocin-induced diabetic mice. Life Sci. 2005, 77, 980-990. [CrossRef]

73. Jeong, H.; Kwon, H.J.; Kim, M.K. Hypoglycemic effect of Chlorella vulgaris intake in type 2 diabetic Goto-Kakizaki and normal Wistar rats. Nutr. Res. Prac. 2009, 3, 23-30.

74. Lu, J.; Zeng, Y.; Hou, W.; Zhang, S.; Li, L.; Luo, X.; Xi, W.; Chen, Z.; Xiang, M. The soybean peptide aglycin regulates glucose homeostasis in type 2 diabetic mice via IR/IRS1 pathway. J. Nutr. Biochem. 2012, 23, 1449-1457. [CrossRef] [PubMed]

75. Veloso, R.V.; Latorraca, M.Q.; Arantes, V.C.; Reis, M.A.; Ferreira, F.; Boschero, A.C.; Carneiro, E.M. Soybean diet improves insulin secretion through activation of cAMP/PKA pathway in rats. J. Nutr. Biochem. 2008, 19, 778-784. [PubMed] 
76. Roblet, C.; Akhtar, M.J.; Mikhaylin, S.; Pilon, G.; Gill, T.; Marette, A.; Bazinet, L. Enhancement of glucose uptake in muscular cell by peptide fractions separated by electrodialysis with filtration membrane from salmon frame protein hydrolysate. J. Funct. Foods 2016, 22, 337-346.

77. Kwon, D.Y.; Daily, J.W.; Kim, H.J.; Park, S. Antidiabetic effects of fermented soybean products on type 2 diabetes. Nutr. Res. 2010, 30, 1-13. [CrossRef]

78. Martinez-Villaluenga, C.; Bringe, N.A.; Berhow, M.A.; Gonzalez, de Mejia, E. B-conglycinin embeds active peptides that inhibit lipid accumulation in 3T3-L1 adipocytes In Vitro. J. Agric. Food Chem. 2008, 56, 10533-10543. [CrossRef] [PubMed]

79. Martinez-Villaluenga, C.; Dia, V.P.; Berhow, M.; Bringe, N.A.; Gonzalez de Mejia, E. Protein hydrolysates from $\beta$-conglycinin enriched soybean genotypes inhibit lipid accumulation and inflammation In Vitro. Mol. Nutr. Food Res. 2009, 53, 1007-1018. [CrossRef] [PubMed]

80. Kim, E.D.; Kim, E.; Lee, J.H.; Hyun, C.K. Gly-Ala-Gly-Val-Gly-Tyr: A novel synthetic peptide; improves glucose transport and exerts beneficial lipid metabolic effects in 3T3-L1 adipoctyes. Eur. J. Pharmacol. 2011, 650, 479-485. [CrossRef]

81. Hammé, V.; Sannier, F.; Piot, J.M.; Bordenave-Juchereau, S. Effects of lactokinins from fermented acid goat whey on lipid content and adipogenesis of immortalised human adipocytes. Int. Dairy J. 2010, 20, 642-645. [CrossRef]

82. Yim, M.J.; Hosokawa, M.; Mizushina, Y.; Yoshida, H.; Saito, Y.; Miyashita, K. Suppressive effects of Amarouciaxanthin A on 3T3-L1 adipocyte differentiation through downregulation of PPAR $\gamma$ and C/EBP $\alpha$ mRNA expression. J. Agric. Food Chem. 2011, 59, 1646-1652. [PubMed]

83. Ben, Henda, Y.; Laamari, M.; Lanneluc, I.; Travers, M.A.; Agogué, H.; Arnaudin, I.; Bridiau, N.; Maugard, T.; Piot, J.M.; Sannier, F.; et al. Di and tripeptides from marine sources can target adipogenic process and contribute to decrease adipocyte number and functions. J. Funct. Foods 2015, 17, 1-10.

84. Wang, L.L.; Hao, S.; Zhang, S.; Guo, L.J.; Hu, C.Y.; Zhang, G.; Gao, B.; Zhao, J.J.; Jiang, Y.; Tian, W.G.; et al. $\mathrm{PTEN} / \mathrm{PI} 3 \mathrm{~K} / \mathrm{AKT}$ protein expression is related to clinicopathologic features and prognosis in breast cancer with axillary lymph node metastases. Hum. Pathol. 2017, 61, 49-57. [PubMed]

85. Govers, R. Molecular mechanisms of GLUT4 regulation in adipocytes. Diabetes Metab. 2014, 40, 400-410. [CrossRef]

86. Morino, K.; Neschen, S.; Bilz, S.; Sono, S.; Tsirigotis, D.; Reznick, R.M.; Moore, I.; Nagai, Y.; Samuel, V.; Sebastian, D.; et al. Muscle-specific IRS-1 Ser->Ala transgenic mice are protected from fat-induced insulin resistance in skeletal muscle. Diabetes 2008, 57, 2644-2651. [CrossRef] [PubMed]

87. Bozulic, L.; Hemmings, B.A. PIKKing on PKB regulation of PKB activity by phosphorylation. Curr. Opin. Cell Biol. 2009, 21, 256-261. [PubMed]

88. Davis, J.; Higginbotham, A.; O'Connor, T.; Moustaid-Moussa, N.; Tebbe, A.; Kim, Y.C.; Cho, K.W.; Shay, N.; Adler, S.; Peterson, R.; et al. Soy protein and isoflavones influence adiposity and development of metabolic syndrome in the obese male ZDF rat. Ann. Nutr. Metab. 2007, 51, 42-52. [PubMed]

89. Nordentoft, I.; Jeppesen, P.B.; Hong, J.; Abudula, R.; Hermansen, K. Increased insulin sensitivity and changes in the expression profile of key insulin regulatory genes and $\beta$ cell transcription factors in diabetic KKAy-mice after feeding with a soy bean protein rich diet high in isoflavone content. J. Agric. Food Chem. 2008, 56, 4377-4385. [CrossRef] [PubMed]

90. Han, B.K.; Lee, H.J.; Lee, H.S.; Suh, H.J.; Park, Y. Hypoglycaemic effects of functional tri-peptides from silk in differentiated adipocytes and streptozotocin-induced diabetic mice. J. Sci. Food Agric. 2016, 96, 116-121.

91. Huang, K.C.; Huang, H.J.; Chen, C.C.; Chang, C.T.; Wang, T.Y.; Chen, R.H.; Chen, Y.C.; Tsai, F.J. Susceptible gene of stasis-stagnation constitution from genome-wide association study related to cardiovascular disturbance and possible regulated traditional Chinese medicine. BMC Complement. Altern. Med. 2015, 15, 229. [CrossRef] [PubMed]

92. McCurdy, C.E.; Klemm, D.J. Adipose tissue insulin sensitivity and macrophage recruitment Does PI3K pick the pathway? Adipocyte 2013, 21, 135-142.

93. Zhang, Y.; Hai, J.; Cao, M.; Zhang, Y.; Pei, S.; Wang, J.; Zhang, Q. Silibinin ameliorates steatosis and insulin resistance during non-alcoholic fatty liver disease development partly through targeting IRS-1/PI3K/Akt pathway. Int. Immunopharmacol. 2013, 17, 714-720. [PubMed] 
94. Ishihara, K.; Oyaizu, S.; Fukuchi, Y.; Mizunoya, W.; Segawa, K.; Takahashi, M.; Mita, Y.; Fukuya, Y.; Fushiki, T.; Yasumoto, K. A soybean peptide isolate diet promotes postprandial carbohydrate oxidation and energy expenditure in type II diabetic mice. J. Nutr. 2003, 133, 752-757. [PubMed]

95. Zhu, K.N.; Jiang, C.H.; Tian, Y.S.; Xiao, N.; Wu, Z.F.; Ma, Y.L.; Lin, Z.; Fang, S.Z.; Shang, X.L.; Liu, K.; et al. Two triterpeniods from Cyclocarya paliurus ( $\beta 1$ Iljinsk (Juglandaceae) promote glucose uptake in 3T3-L1 adipocytes: The relationship to AMPK activation. Phytomedicine 2015, 22, 837-846.

96. Butler, A.E.; Janson, J.; Bonner-Weir, S.; Ritzel, R.; Rizza, R.A.; Butler, P.C. $\beta$-cell deficit and increased $\beta$-cell apoptosis in humans with type 2 diabetes. Diabetes 2003, 52, 102-110. [PubMed]

97. Mizoguchi, T.; Takehara, I.; Masuzawa, T.; Saito, T.; Naoki, Y. Nutrigenomic studies of effects of Chlorella on subjects with high-risk factors for lifestyle-related disease. J. Med. Food 2008, 11, 395-404. [PubMed]

98. Panahi, Y.; Ghamarchehreh, M.E.; Beiraghdar, F.; Zare, R.; Jalalian, H.R.; Sahebkar, A. Investigation of the effects of Chlorella vulgaris supplementation in patients with non-alcoholic fatty liver disease: A randomized clinical trial. Hepatogastroenterology 2012, 59, 2099-2103. [PubMed]

99. Ebrahimi-Mameghani, M.; Sadeghi, Z.; Farhangi, M.A.; Vaghef-Mehrabany, E.; Aliashrafi, S. Glucose homeostasis, insulin resistance and inflammatory biomarkers in patients with non-alcoholic fatty liver disease: Beneficial effects of supplementation with microalgae Chlorella vulgaris: A double-blind placebo-controlled randomized clinical trial. Clin. Nutr. 2016. [CrossRef]

100. Jo, B.H.; Lee, C.S.; Song, H.R.; Lee, H.G.; Oh, H.M. Development of novel microsatellite markers for strain-specific identification of Chlorella vulgaris. J. Microbiol. Biotechnol. 2014, 24, 1189-1195.

101. Kim, M.; Kim, E.; Kwak, H.S.; Jeong, Y. The ingredients in Saengshik; a formulated health food; inhibited the activity of $\alpha$-amylase and $\alpha$-glucosidase as anti-diabetic function. Nutr. Res. Pract. 2014, 8, 602-606. [PubMed]

102. Ren, Y.; Liang, K.; Jin, Y.; Zhang, M.; Chen, Y.; Wu, H.; Lai, F. Identification and characterization of two novel $\alpha$-glucosidase inhibitory oligopeptides from hemp (Cannabis sativa L.) seed protein. J. Funct. Foods 2016, 26, 439-450. [CrossRef]

103. Ngoh, Y.Y.; Gan, C.Y. Enzyme-assisted extraction and identification of antioxidative and $\alpha$-amylase inhibitory peptides from Pinto beans (Phaseolus. vulgaris cv. Pinto). Food Chem. 2016, 190, 331-337. [PubMed]

104. Siow, H.L.; Gan, C.Y. Extraction; identification; and structure-activity relationship of antioxidative and $\alpha$-amylase inhibitory peptides from cumin seeds (Cuminum. cyminum). J. Funct. Foods 2016, 22, 1-12. [CrossRef]

105. Siow, H.L.; Lim, T.S.; Gan, C.Y. Development of a workflow for screening and identification of $\alpha$-amylase inhibitory peptides from food source using an integrated Bioinformatics-phage display approach Case study-Cumin seed. Food Chem. 2017, 214, 67-76. [CrossRef]

106. Mojica, L.; de Mejia, E.G. Optimization of enzymatic production of anti-diabetic peptides from black bean (Phaseolus. vulgaris L.) proteins; their characterization and biological potential. Food. Funct. 2016, 7, 713-727.

107. Uraipong, C.; Zhao, J. Rice bran protein hydrolysates exhibit strong in vitro $\alpha$-amylase; $\beta$-glucosidase and ACE-inhibition activities. J. Sci. Food Agric. 2016, 96, 1101-1110. [CrossRef]

108. Yu, Z.; Yin, Y.; Zhao, W.; Liu, J.; Chen, F. Anti-diabetic activity peptides from albumin against $\alpha$-glucosidase and $\alpha$-amylase. Food Chem. 2012, 135, 2078-2085. [CrossRef]

109. Mojica, L.; Luna-Vital, D.A.; Gonzalez de Mejia, E. Characterization of peptides from common bean protein isolates and their potential to inhibit markers of type-2 diabetes; hypertension and oxidative stress. J. Sci. Food Agric. 2016. [CrossRef]

110. Engel, M.; Hoffmann, T.; Wagner, L.; Wermann, M.; Heiser, U.; Kiefersauer, R.; Huber, R.; Bode, W.; Demuth, H.U.; Brandstetter, H. The crystal structure of dipeptidyl peptidase IV (CD26) reveals its functional regulation and enzymatic mechanism. Proc. Natl. Acad. Sci. USA 2003, 100, 5063-5068. [CrossRef]

111. Juillerat-Jeanneret, L. Dipeptidyl peptidase IV and its inhibitors therapeutics for type 2 diabetes and what else? J. Med. Chem. 2014, 57, 2197-2212.

112. Nongonierma, A.B.; FitzGerald, R.J. Susceptibility of milk protein-derived peptides to dipeptidyl peptidase IV (DPP-IV) hydrolysis. Food Chem. 2014, 145, 845-852.

113. Lu, I.L.; Tsai, K.C.; Chiang, Y.K.; Jiaang, W.T.; Wu, S.H.; Mahindroo, N.; Chien, C.H.; Lee, S.J.; Chen, X.; Chao, Y.S.; et al. A three-dimensional pharmacophore model for dipeptidyl peptidase IV inhibitors. Eur. J. Med. Chem. 2008, 43, 1603-1611. [CrossRef] 
114. Nongonierma, A.B.; Gaudel, C.; Murray, B.A.; Flynn, S.; Kelly, P.M.; Newsholme, P.; FitzGerald, R.J. Insulinotropic properties of whey protein hydrolysates and impact of peptide fractionation on insulinotropic response. Int. Dairy J. 2013, 32, 163-168.

115. Dixon, G.; Nolan, J.; McClenaghan, N.; Flatt, P.R.; Newsholme, P. A comparative study of amino acid consumption by rat islet cells and the clonal $\beta$-cell line BRIN-BD11-the functional significance of L-alanine. J. Endocrinol. 2003, 179, 447-454.

116. Bender, K.; Newsholme, P.; Brennan, L.; Maechler, P. The importance of redox shuttles to pancreatic $\beta$-cell energy metabolism and function. Biochem. Soc. Trans. 2006, 34, 811-814. [CrossRef]

117. Power, O.; Hallihan, A.; Jakeman, P. Human insulinotropic response to oral ingestion of native and hydrolysed whey protein. Amino Acids 2009, 37, 333-339. [CrossRef]

118. Horner, K.; Drummond, E.; Brennan, L. Bioavailability of milk protein-derived bioactive peptides a glycaemic management perspective. Nutr. Res. Rev. 2016, 29, 91-101. [CrossRef]

119. Manders, R.J.; Koopman, R.; Sluijsmans, W.E.; van den Berg, R.; Verbeek, K.; Saris, W.H.; Wagenmakers, A.J.; van Loon, L.J. Co-ingestion of a protein hydrolysate with or without additional leucine effectively reduces postprandial blood glucose excursions in Type 2 diabetic men. J. Nutr. 2006, 136, 1294-1299.

120. Manders, R.J.; Praet, S.F.; Meex, R.C.; Koopman, R.; De Roos, A.L.; Wagenmakers, A.J.; Saris, W.H.; Van Loon, L.J. Protein hydrolysate/leucine co-ingestion reduces the prevalence of hyperglycemia in type 2 diabetic patients. Diabetes Care 2006, 29, 2721-2722.

121. Ngoh, Y.Y.; Lim, T.S.; Gan, C.Y. Screening and identification of five peptides from pinto bean with inhibitory activities against $\alpha$-amylase using phage display technique. Enzyme. Microb. Technol. 2016, 89, 76-84.

122. Ochiai, T.; Sugita, T.; Kato, R.; Okochi, M.; Honda, H. Screening of an $\alpha$-amylase inhibitor peptide by photolinker-peptide array. Biosci. Biotechnol. Biochem. 2012, 76, 819-824. [CrossRef]

(C) 2017 by the authors. Licensee MDPI, Basel, Switzerland. This article is an open access article distributed under the terms and conditions of the Creative Commons Attribution (CC BY) license (http:/ / creativecommons.org/licenses/by/4.0/). 